\title{
On Malaysian House Price Growth: The Effects of Market Sentiments
}

\author{
Calvin W. H. Cheong (Corresponding author) \\ Faculty of Business, Design and Arts, Swinburne University of Technology Sarawak \\ Jalan Simpang Tiga, 93350 Kuching, Malaysia
}

Tel: 60-82-260-996 E-mail: ccheong@swinburne.edu.my

Lisa L. H. Ngui

Faculty of Business, Design and Arts, Swinburne University of Technology Sarawak Jalan Simpang Tiga, 93350 Kuching, Malaysia

Tel: 60-82-260-706 E-mail: lngui@swinburne.edu.my

\begin{abstract}
Shella Georgina Beatrice
Faculty of Business, Design and Arts, Swinburne University of Technology Sarawak Jalan Simpang Tiga, 93350 Kuching, Malaysia
\end{abstract}

Tel: 60-82-260-940 E-mail: sbeatrice@swinburne.edu.my

Received: Nov. 13, 2018 Accepted: Dec. 18, 2018 Published: December18, 2018

doi:10.5296/ajfa.v10i2.13900 URL: https://doi.org/10.5296/ajfa.v10i2.13900

\begin{abstract}
This paper examines the factors that drive the recent exponential growth in Malaysian house prices. We first construct a sentiment index for the housing market in Malaysia guided by the methods employed by Baker and Wurgler (2006). Preliminary analyses of our bias-free sentiment index indicate a strong correlation with overall market confidence which attests to the reliability of our index. The results also show contemporaneous sentiment to strongly influence future housing market returns especially in the short-term. Contrary to the literature, our results suggest that it is property developer behaviour that drive sentiments and property prices. The study contributes to the literature by providing an easily generalizable method of constructing a housing market sentiment index in other countries that holistically accounts for
\end{abstract}




\section{Macrothink}

Asian Journal of Finance \& Accounting ISSN 1946-052X 2018, Vol. 10, No. 2

essential housing market elements that are otherwise ignored in confidence indices. This study also contributes to practice as it provides evidence to policy-makers who wish to cool property markets may want to design interventions that are targeted at property developers instead of home-buyers or speculators.

Keywords: House prices, Market sentiments, Property market, Property returns 


\section{Introduction}

Classical economic and finance theory rely on the assumption of rational investors to work. On this assumption, all assets are priced without influence from the sentiments of the interested parties. Even if pricing errors exist, they will have no long-term impact on prices, as they will quickly be arbitraged away. However, literature over the past decade has shown that we can no longer rely on this assumption. Commonly defined as the propensity of investors to behave in a manner that is not justified by the exogenous information at hand, investor sentiments have been shown to have significant influence over asset prices (Baker \& Wurgler, 2006; 2007). The effects are no different in the housing market (Clayton, Ling, and Naranjo, 2009; Hui, Zheng, and Wang, 2013). In fact, Clayton, MacKinnon, and Peng (2008) contend that effects of investor sentiments in the housing market are stronger due to the market's illiquid nature and a lack of short-selling mechanisms. An absence of short-selling mechanisms restricts the market's ability to correct mispricings (Clayton et al., 2008). As a result, investors in the private housing market become more susceptible to sentiments especially since they comprise individuals and households that have less ability and access to complete information.

Years of persistent house price growth in Malaysia over the past decade has reignited fears of another Asian Financial Crisis that sends prices tumbling after the bubble bursts. To allay these fears, the Malaysian government, and the central bank, Bank Negara Malaysia (BNM), introduced various monetary, fiscal, and legislative measures in hopes of slowing the growth in house prices. Market participants however, opine that these measures have only succeeded in reducing the number of transactions taking place, and not the price of the house itself (Yeong, 2014). Matters are exacerbated when parties with surplus financial resources artificially inflate resale prices after securing substantial discounts from developers. BNM itself has indicated that the growth in house prices are not in line with long-term averages as well as economic fundamentals, attributing the growth to market sentiment and speculation (Hisyam, 2013). This raises questions on the drivers of house price growth in Malaysia. Does market optimism drive house prices in Malaysia? Can a reliable and holistic measure of property market sentiments be built for Malaysia? This paper seeks to answer these questions.

The primary region of focus in our study is the West Coast of Peninsular Malaysia. The reasons behind this focus are manifold. First, many economic policies have been focused on this part of the country leading to a disparity in development, pricing, and inflation between states. To put things into perspective, an apartment unit in the state of Selangor measuring 1,000 square feet will cost anywhere between MYR350,000 to MYR1 million. A similarly sized unit in say, Kuantan, a city on the East Coast of Peninsular Malaysia will cost only half that. Various commentators have cited speculation and sentiment as the reason behind this difference providing us with an ideal setting to test for market sentiments. Second, developer activity has been heavily concentrated in this region of Malaysia. Demand for housing continue to rise as economic opportunities continue to attract emigrants from other states of Malaysia. This again, provides a suitable backdrop to evaluate factors affecting house prices and market sentiments. Third, detailed records of transactions maintained by the National Property Information Centre (NAPIC) provides us with valuable data to observe and analyse 
micro-level trends within the Malaysian housing market.

We begin our study with a construction of a sentiment index following Baker and Wurgler (2006). This first required proxies that reflected sentiments in the Malaysian housing market, selected intuitively with reference to prior literature. We then perform a principal component analysis on the sentiment proxies to determine which among them had the strongest impact on sentiments before regressing each of the proxies against economic fundamentals variables to negate the effects of business and economic cycle variations. We then use a partial least squares (PLS) regression to derive a housing market sentiment index. We find our sentiment index to be strongly correlated with Malaysia's consumer and business confidence index. To be precise, we find the correlation between our sentiment index and business confidence to be greater than its correlation with consumer confidence. Since the literature suggests that sentiments drive asset prices and returns, we assess our sentiment index's reliability in predicting housing market returns. We find a positive relationship between housing market sentiments and current returns as well as future returns. However, contrary to the literature (e.g. Stambaugh, Yu \& Yuan, 2012; Berger \& Turtle, 2015; Zhou, 2017), we find periods of high sentiment to be followed by higher returns.

Several contributions arise from this study. First, our approach in measuring housing market sentiments by way of proxies complements that of Soo (2013) who used a textual analysis approach and Hui and Wang (2014). Our approach also complements Zhou (2017) in that we show how the proxy selection process can be adapted in ways that best reflect local market conditions and data availability. This not only improves the relevancy of the index but also its comprehensiveness and reliability. The ease of its construction also provides a simple guide for the government and other parties interested in monitoring housing market conditions to replicate. Second, our results empirically confirm the opinions of various market commentators on the role of property developers in drumming up sentiments and subsequently, house prices. Specifically, our results provide evidence to show that the interventions currently in place are incorrectly targeted at house-buyers. To be effective, policies that attempt to cool the property market should be targeted at property developers.

The rest of this paper is as follows. Section 2 provides a brief history on the Malaysian housing market and a review of literature on sentiments in the housing market. In Section 3 we detail the process of constructing the sentiment index. In Section 4 we show the results to our tests. Section 5 provides a discussion of results and implications before concluding.

\section{Literature Review}

\subsection{A Recent History of the Malaysian Housing Market}

For over a decade prior to 2010, national house prices (as measured by the house price index, HPI) were on an upward trend that was in line with the long-term average annual growth of house prices of 3.2 percent, as well as national income levels and economic development (BNM, 2010). However, from Q1 2010 to Q3 2014, national house prices exceeded the average annual growth with a year-on-year increase of 9.41 percent. A large part of this sudden growth was the result of sharp rises in the three largest urban centres of Malaysia, 
namely the Greater Klang Valley, Penang, and Johor. House prices in these regions grew at a rate of $11.38,10.60$, and 10.36 percent respectively, outstripping the already high national average.

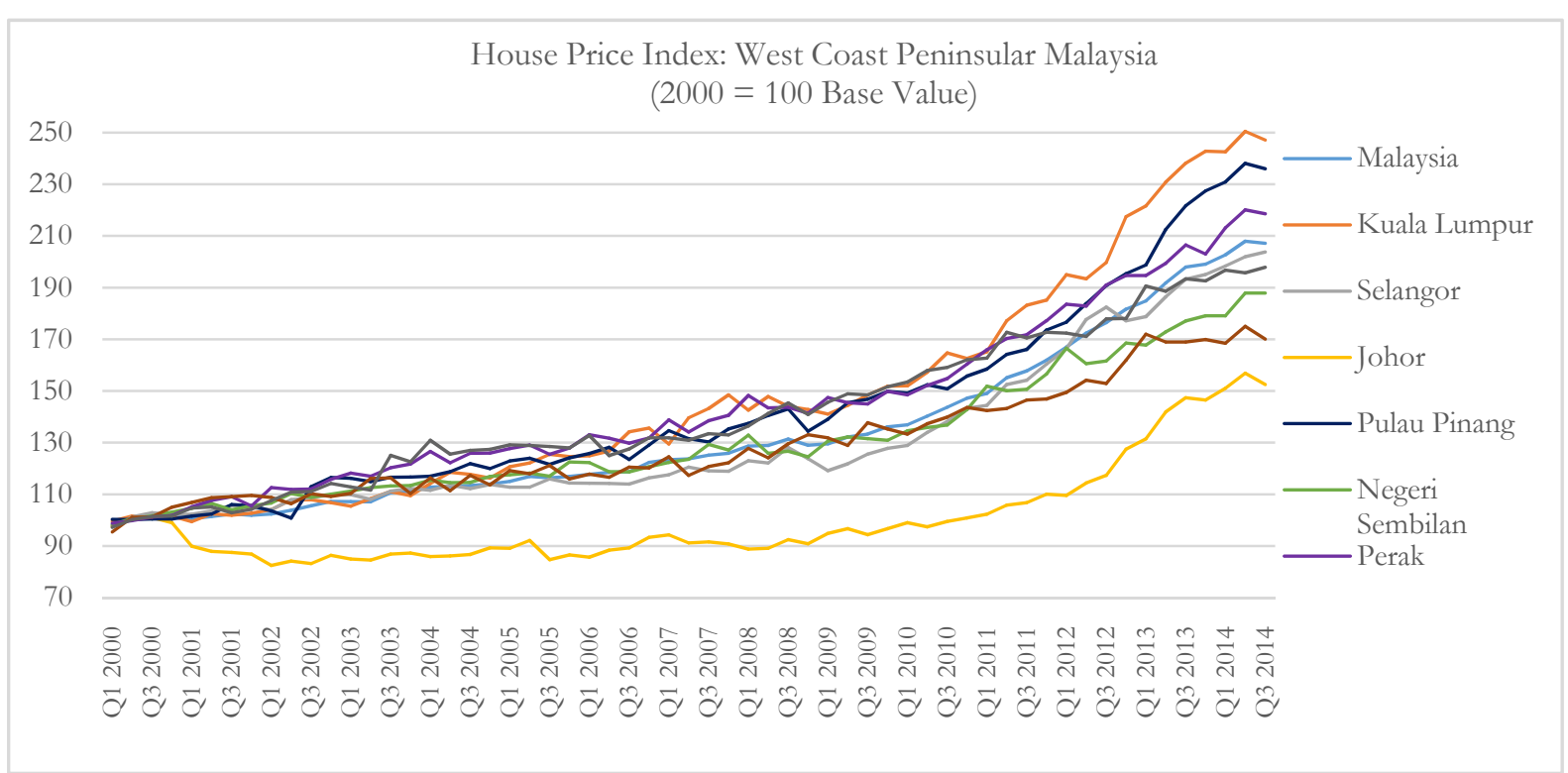

Figure 1. Growth in the Malaysian house price index, Q1 2000 - Q3 2014, by state. Source:

\section{CEIC}

As we can see from Figure 1, on average, the HPI for the whole country rose by about 80 points between Q1 2010 to Q3 2014. In that same period, the HPI for the Greater Klang Valley (i.e. Kuala Lumpur and Selangor) collectively rose by 180 points while the HPI for Penang and Johor rose by 90 and 60 points respectively. Findings from a survey conducted by the International Monetary Fund (2015) (see Figure 2) found further evidence that showed how house prices had exceeded national income and rent.

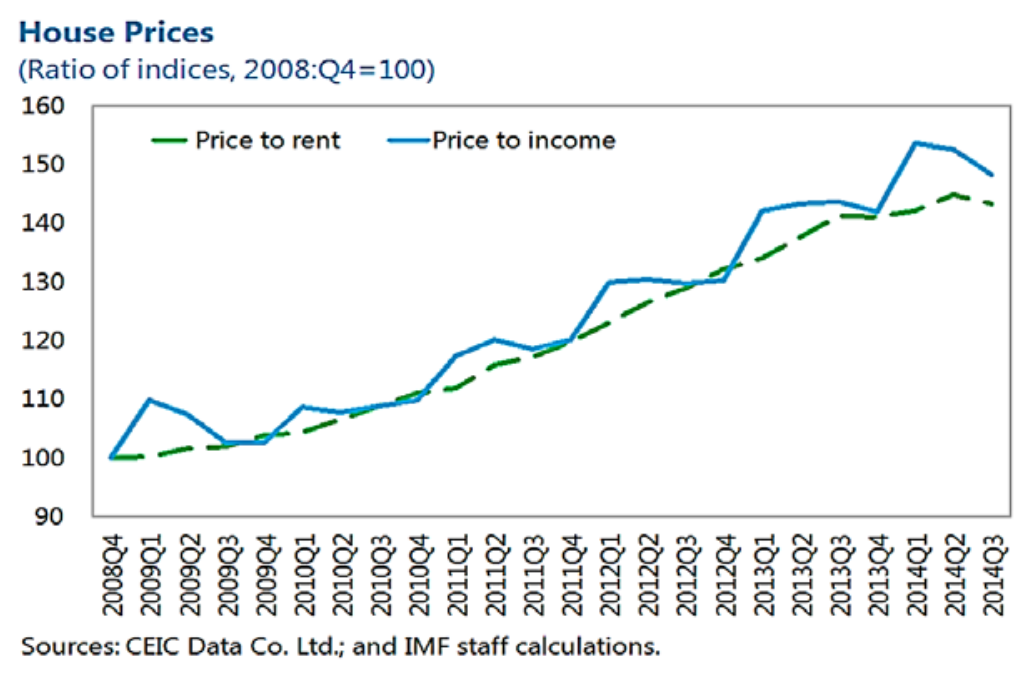

Figure 2. House prices to rent and income. Source: IMF (2015) 
BNM acknowledges the misalignment of prices in these regions against the national average, suggesting that such growth rates were strong signals of speculative investment activity. BNM also recognised the danger of the rising house prices that were not in line with income and population growth figures, giving rise to what commentators fear would be an over-optimistic, overheated property market, and eventually housing bubble (Daily Express, 2015; Hisyam, 2013). House price trends in recent years brings to mind the Asian Financial Crisis of the late 90s. The crisis, particularly in Thailand, Hong Kong, Singapore, and Malaysia had illustrated the effects of excessive exposure to the housing market. Prior to the crisis, houses were used as a form of tradeable asset for capital gains instead of fulfilling residential needs. As house prices began to reach unsustainable highs, speculators lost confidence and began selling off their property holdings from their portfolios. Plunging house prices soon led to costly financial market crashes and economic recession in many Asian countries that were highly dependent on houses as collateral (Herrera \& Perry, 2003; Pomerleano, 2003). There is a genuine concern that the housing market will crash in 2018 after it was revealed that the number of unsold residential units rose by 40 percent (Kaur, 2017). Representatives of developer associations however, rubbished claims that there will be a crash in the coming months, arguing that market optimism and housing demand will persist (Augustin, 2017) as buyers will find different means of supporting their purchases, or adjust their expectations. The accuracy of these claims notwithstanding, they are highly indicative of the influence sentiments have in the housing market; and warrants further study.

Recognizing the dangers of an overheated housing market, the Malaysian government and BNM introduced various fiscal and monetary measures in an attempt to curb speculative activity, and improve housing affordability. First, BNM imposed a limit to the loan-to-value (LTV) on personal third and subsequent mortgages at 70 percent (BNM, 2013; Kamalavacini, 2014). The LTV for first and second mortgages were not affected, and are still dependent on each bank's internal credit policies but BNM raised the capital risk-weights to 100 percent for personal mortgages with LTVs exceeding 90 percent. The Malaysian government on the other hand, re-introduced the real property gains tax (RPGT) in 2010 after a 3-year suspension before gradually raising the rates over the years. When this study was undertaken, the RPGT rates stood at $30 \%$ for houses sold within the first three years; $20 \%$ for houses sold in the fourth year; and $15 \%$ for houses sold in the fifth year. The RPGT aimed to discourage speculators from entering the housing market for capital gains from 'flipping', as more tax is to be paid for a shorter 'flipping' duration. The government also established Perbadanan PR1MA Malaysia under the PR1MA Act 2012; a government-owned developer tasked to construct housing projects that are affordable to the middle-income group. These housing projects are located in key urban centres around the country, and are built to compete with the design and build quality of private developers in the country. Open to only Malaysian citizens, the PR1MA projects are meant to curb speculative activity in the housing market by firstly cutting out the middlemen, and secondly, imposing various restrictions on eligibility of applicants. Finally, the government in October 2013 abolished the Developer Interest Bearing Scheme (DIBS). DIBS allowed developers to bear the interest cost for buyers until the projects were completed, in hopes of lowering the barriers to ownership especially for first-time house-buyers. Despite these measures, house prices continued to rise rapidly 
(Yeong, 2014) which raises the question of what drives house prices in Malaysia.

\subsection{Sentiments in the Housing Market}

For many years, the decision-making behind property purchases was assumed to be a rational process, utilizing factual data, leading to optimal decisions. In instances where there are data deficiencies, buyers turn to market sentiments to augment their decisions and pricing (Gallimore and Gray, 2002). This however is problematic as the housing market has a number of discerning features that makes pricing difficult. First is the high percentage of individual traders, all of whom have very individualised criteria in asset selection and pricing. Second, the housing market is a market for lemons. Unlike the stock market where information asymmetry is reduced through various disclosure mechanisms, developers, sellers or real estate agents have an incentive to withhold information if they feel that it will help them get the best price. The lack of a centralised market makes pricing opaque and difficult to compare across asset types and locations. Also, without a short-sale mechanism, overvalued assets will remain overvalued until such a time when the market decides otherwise. It is for these reasons that the housing market is highly vulnerable to sentiment-induced mispricing (Clayton et al., 2009; Hui \& Wang, 2014). Moreover, it only takes optimism from a small number of investors to have a huge effect on house prices (Piazessi and Schneider, 2009). Various studies support the notion that house prices are driven by irrational expectations, even under perfect market conditions (Clayton, 1997; Clayton et al., 2009). Jin, Soydemir, and Tidwell (2014) similarly, found irrational consumer sentiment to be a significant exogenous variable in the pricing of U.S. residential real estate. In fact, the susceptibility of the housing market to sentiments - positive in particular - is so strong that so long as there is uncertainty over the economic outlook of the country, and optimistic agents continue to hold firmer views than others do, the housing boom will continue (Burnside, Eichenbaum, \& Rebelo, 2015).

The persistent rise in house prices in Malaysia in spite of the measures introduced by the government and central bank provides an ideal setting for us to conduct this study. Due to inherent structural and policy differences between the housing markets of Malaysia and those seen in prior studies, further investigation into the interactions between various housing market factors, government policy, and sentiment is warranted.

\section{Methodology}

\subsection{Data}

Our data is from the secondary housing market on the West Coast of Peninsular Malaysia, widely acknowledged to be the most developed region in the country. Collectively, the West Coast contributes to approximately 70 percent of the national GDP. The data provided by the National Property Information Centre (NAPIC) included the details of 208,627 secondary housing market transactions along the West Coast, over a 7-year sample period from January 2010 to December 2016. We however, chose to focus on four key states namely Kuala Lumpur, Selangor, Johor, and Penang. These four states alone contribute approximately 50 percent to the national GDP and has been a hotbed of real estate transactions throughout the 
sample period. The secondary market transactions in these four states alone account for approximately 70 percent of the total transactions that occurred on the West Coast. The variables in our data include the district, house address, type, number of floors, lot size, valuation date, transacted price, and the identities of the buyer(s) and seller(s).

\subsection{Housing Market Sentiment Index Proxies}

Sentiment indices were made popular by Baker and Wurgler (2006). While seemingly complex, the construction of a sentiment index is an intuitive process. Instead of using a single indicator (e.g. momentum, turnover) as a measure of sentiment, we introduce sentiment proxies that are directly relevant to the housing market in Malaysia by adopting the process of generating proxies provided by Baker and Wurgler (2006). So far, we identified only three other studies that adopted this approach (see Hui \& Wang, 2014; Ling, Naranjo, \& Scheick, 2014; and Zhou, 2017). We discuss the intuition behind each of our sentiment proxies below.

Malaysia adopts a sale-before-construction system. The system provides a substantial investment incentive to property developers to demand and purchase more land-space as they are able to lock in the profits of the project even before commencement. As demand for land-space and buy-side investment incentives are major determinants of new housing projects (Tse, Ho, \& Ganesan, 1999), it is reasonable to assume that developers are driving and simultaneously sensitive to market sentiments. In Baker and Wurgler (2006), the number of IPOs was a sentiment proxy for the stock market. The greater the number of IPOs, the more optimistic the sentiment. Similarly, we argue that the incoming and completed supply of residential units scaled by the existing stock of residential units in the past quarter reflects sentiments in the housing market. We call this proxy NewStock and expect it to be positively correlated with housing market sentiments.

While news outlets may have reported instances where individuals were able to save up and purchase a home in cash, house prices in Malaysia are well beyond what a significant percentage of the population can afford (Lee, Sinnakkannu, \& Ramasamy, 2015). Furthermore, due to legal and financial restrictions, even if they can afford to pay for it in cash, house buyers in Malaysia must finance the purchase with a mortgage. Some may argue that the distinction between investors and house-consumers (Genesove \& Mayer, 2001) may influence the terms and conditions of the mortgage. However, as mentioned above, the house-buying process in Malaysia is the same for everyone regardless of intention. As the NewStock proxy represents the position of developers, we contend that total residential mortgage divided by total loans in the country represents the position of buyers. We call this proxy ResMort and expect it to be positively correlated with housing market sentiments.

Having accounted for the supply and demand drivers in the housing market, we now consider the matter of liquidity. Liquidity has often been regarded as an indicator of sentiment (Baker and Stein, 2004; Clayton et al., 2008). Rising liquidity in the housing market is a channel through which a pricing-sentiment spiral in the housing market is amplified (Ling, Ooi, \& Le, 2011). Typically, liquidity is measured through turnover. In the housing market, this may be reflected in the length of time the buyer owns the property. However, Malaysia imposes a 30 
percent real property gains tax for holding periods of up to 3 years. This may affect the suitability of the holding period as a proxy for housing market sentiments. Nevertheless, in keeping with the literature, we include the natural log of the median holding period of sellers (in months) as a proxy for turnover. We also propose an alternative. Since we are able to identify the buyer(s) and seller(s) for each transaction, we instead use the number of sub-sales (Note 1) in a month as a proxy for turnover. While it can be argued that sub-sales are also affected by the real property gains tax, they also account for instances where the housing project took longer than 4 years to complete (Note 2). We call these proxies HoldPer and SubSale respectively. We expect HoldPer to be negatively correlated while expecting SubSale to be positively correlated with housing market sentiments.

The final aspect of sentiment we consider here is buyer confidence. The corporate finance literature suggests that overconfident managers are more likely to overinvest or pay a premium on acquisitions when there are surplus funds available (Malmeinder \& Tate, 2005; 2008). Similarly, a buyer's confidence in the housing market and future property values will have a strong part to play in the price paid for the house. The greater their confidence in future house prices, the more they will be willing to pay for the house now. We feel that simply taking the size of the house (in square meters) transacted would not accurately reflect buyer's confidence in Malaysia as there are many large houses that are cheap and vice versa. Instead, we use the transacted price per square meter (in ringgit) as a measure of buyer confidence. It is also not uncommon for sellers to factor various elements (e.g. location, fixtures and fittings, accessibility, security) into their asking prices. The value attached to many of these elements however, are subject to buyer preferences and cannot be captured by the price per square meter measure. As an alternative, we also use the number of transactions that are RM1 million (Note 3) and above in a month as a proxy for buyer confidence. We call these proxies $P S Q M$ and $P 1 M$ respectively. We expect both proxies to be positively correlated with housing market sentiments.

Table 1. Annual averages of the sentiment proxies, $2010-2016$.

\begin{tabular}{rrrrrrr}
\hline Year & NewStock & ResMort & HoldPer & SubSale & PSQM & P1M \\
\hline 2010 & 2.541 & 0.456 & 6.853 & 10.578 & 158.54 & 5.231 \\
2011 & 3.289 & 0.679 & 6.024 & 13.911 & 179.61 & 5.385 \\
2012 & 2.132 & 0.568 & 6.172 & 12.118 & 205.32 & 6.123 \\
2013 & 2.291 & 0.632 & 6.125 & 12.654 & 245.25 & 6.549 \\
2014 & 2.875 & 0.659 & 7.056 & 13.271 & 305.33 & 7.167 \\
2015 & 2.116 & 0.559 & 7.011 & 12.513 & 363.87 & 7.385 \\
2016 & 2.758 & 0.551 & 6.954 & 12.245 & 401.51 & 8.134 \\
\hline
\end{tabular}

Table 1 provides the annual averages of the six proposed proxies of housing market sentiments from 2010 to 2016. The proxies reached peaked averages in 2011 except for PSQM and P1M. The numbers fell in 2012 after the PR1MA project was launched at the end of 2011, after which they rose until 2014, the same year the DIBS was abolished, which slowed down the figures in 2015 before climbing again in 2016. While NewStock, ResMort, HoldPer, and SubSale may be correlated with economic fundamentals, and affected by 
cooling measures, both $P S Q M$ and $P 1 M$ continued to rise regardless, suggesting a high level of confidence in house prices. The pertinent question here is what is driving these prices.

\subsection{Constructing the Sentiment Index}

We begin by negating the effects of business cycle variations and macro factors from the proxies through an orthogonalization process by regressing each of the standardised sentiment proxies on eight economic fundamental variables (Ling, et al., 2014). The eight variables are the Purchasing Manager's Index $(P M I)$, the Industrial Production Index (IPI), the profit margin of the real estate industry in the last calendar year $(R E P)$, the growth of the Consumer Price Index (CPI), and the growth of M2 (M2). We include total loans to the property sector divided by the total loans in the country $(T L P)$ as a reflection of the developers' access to credit. We also include $N P L$, which is the total non-performing loans to the real estate market divided by the total loans in the country to account for the risks of loan defaults. Finally, we also include $B L R+$ which is the average premium (discount) charged by banks in the country above (below) the base lending rate determined by the central bank to negate the interest rate incentive effect. The residuals from these regressions should thus contain a measure of housing market sentiment that is orthogonal to business cycle and macro factors. We then perform a three-month smoothing of the residuals (Huang, Jiang, Tu, and Zhou, 2014).

This is followed by a principal component analysis for all sentiment proxies and their one-month lagged values. This is to account for the possibility that one proxy may have an impact on another in the future (Baker \& Wurgler, 2006). We then compute the correlation between the first principal component $(P 1)$ and each of the current and lagged proxies. Whichever proxy has the highest statistically significant correlation magnitude is chosen as a proxy for our housing market sentiment.

Table 2. Current and lagged sentiment proxy correlation with the first principal component, $P 1$

\begin{tabular}{llllll}
\hline Current & Correlation with $P 1$ & Obs. & 1-month Lag & Correlation with $P 1$ & Obs. \\
\hline NewStock & $0.815^{* * *}$ & 83 & NewStock & $0.754^{* *}$ & 83 \\
ResMort & $0.787^{* * *}$ & 83 & ResMort & $0.511^{* * *}$ & 83 \\
HoldPer & $-0.523^{* * *}$ & 83 & HoldPer & $-0.428^{* *}$ & 83 \\
SubSale & $0.519^{* * *}$ & 83 & SubSale & $0.476^{* * *}$ & 83 \\
PSQM & $0.654^{* * *}$ & 83 & PSQM & $0.793^{* * *}$ & 83 \\
P1M & 0.058 & 83 & P1M & 0.132 & 83 \\
\hline
\end{tabular}

The principal component analysis suggests the selection of the current value of NewStock, ResMort, HoldPer, SubSale, and the lagged value of PSQM as our housing market sentiment proxies. 


$$
\begin{gathered}
P x_{i, t-1}=\beta_{i, 0, t}+\beta_{i, 1, t} R_{t}+\beta_{i, 2, t} R_{t-1}+e_{i, t-1} \\
P x_{i, t}=\alpha_{t}+S_{t}+v_{i, t}
\end{gathered}
$$

Finally, we estimate a partial least squares regression (1) to construct a look-ahead-bias-free sentiment index (Huang et al., 2014). We estimate Equation 1 for each of our chosen proxies, $P x_{i}$, where $R_{t}$ is the housing market return at time $t$. The series $\beta_{i, 1, t}$ captures the time-varying sensitivity of $P x_{i}$ to the market sentiment instrumented by future housing market returns (Note 4). Including $R_{t-1}$ on the right side of Equation 1 is intuitive in the Malaysian market since transacted prices are also driven by previous transacted prices in the same locale. It also controls for short-term reversals (Zhou, 2017). After estimating Equation 1, we then perform a cross-sectional regression (Equation 2), where the independent variable is the loadings estimated from Equation 1. The time series of the slope $S$ represents our sentiment index.

\section{Results \& Discussion}

\subsection{A Simple Illustration}

Our sentiment index from January 2010 to December 2016 has a mean of 0.521 and a median of 0.548 . The index had a maximum value of 0.991 , a minimum value of 0.028 , and a standard deviation of 0.299 . In Figure 3 below, we plot our sentiment index against Malaysia's house price index. House prices in Malaysia has been on the rise since 2010 and has yet to show any signs of slowing down, despite the steps taken by the government to curb speculation and to cool overheating prices. In the same period, housing market sentiments have fluctuated, peaking towards the end of 2011. A cursory glance at Figure 3 suggests that the policies implemented by the government has done little to curb housing market sentiments and rising house prices. For example, when the government launched the PR1MA project in Q4 2011, sentiments fell before climbing up again within a few months. Similarly, when the government announced the abolishment of the DIBS in Q4 2013, sentiments fell before climbing up again in the next quarter. It would seem that Malaysian housing market sentiments are driven by other factors and are not affected by government policy.

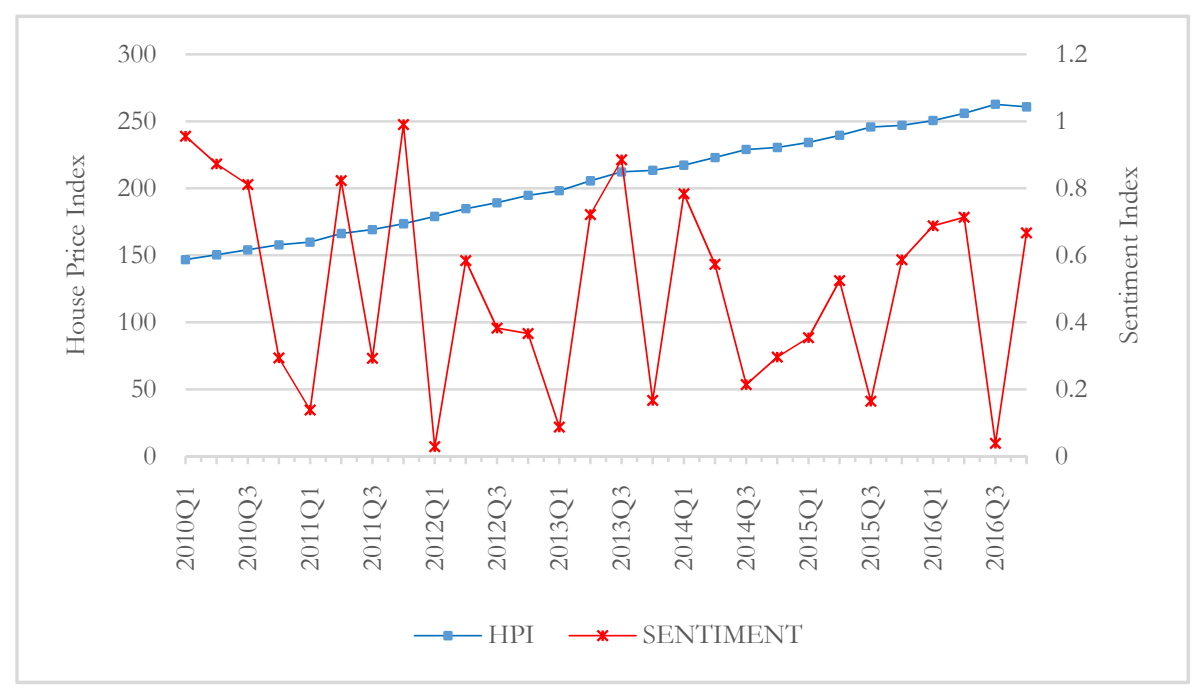

Figure 3. House Price Index and the sentiment index, January 2010 - December 2016 


\section{I Macrothink}

Asian Journal of Finance \& Accounting

ISSN 1946-052X 2018, Vol. 10, No. 2

To establish the reliability of our sentiment index, we first plot our sentiment index against a couple of confidence indices for the country. As of writing, the only available confidence indices for Malaysia was the consumer confidence and business confidence index. We reason that these indices suffice for Malaysia since the housing market not only attracts consumers and investors (Han, 2013; Miller \& Pandher, 2008) but businesses (i.e. property developers) as well. The consumer confidence index would thus represent consumer and investor outlook while the business confidence index represents developer outlook. In Figure 4 below, we can see that our sentiment index seems to move in the same direction as the consumer and business confidence index. The correlation between our sentiment index and the consumer confidence index is 0.41 while correlation between our sentiment index and the business confidence is 0.56 (Note 5). What this seems to suggest is housing market sentiments in Malaysia are more strongly driven by developers instead of consumers and investors.

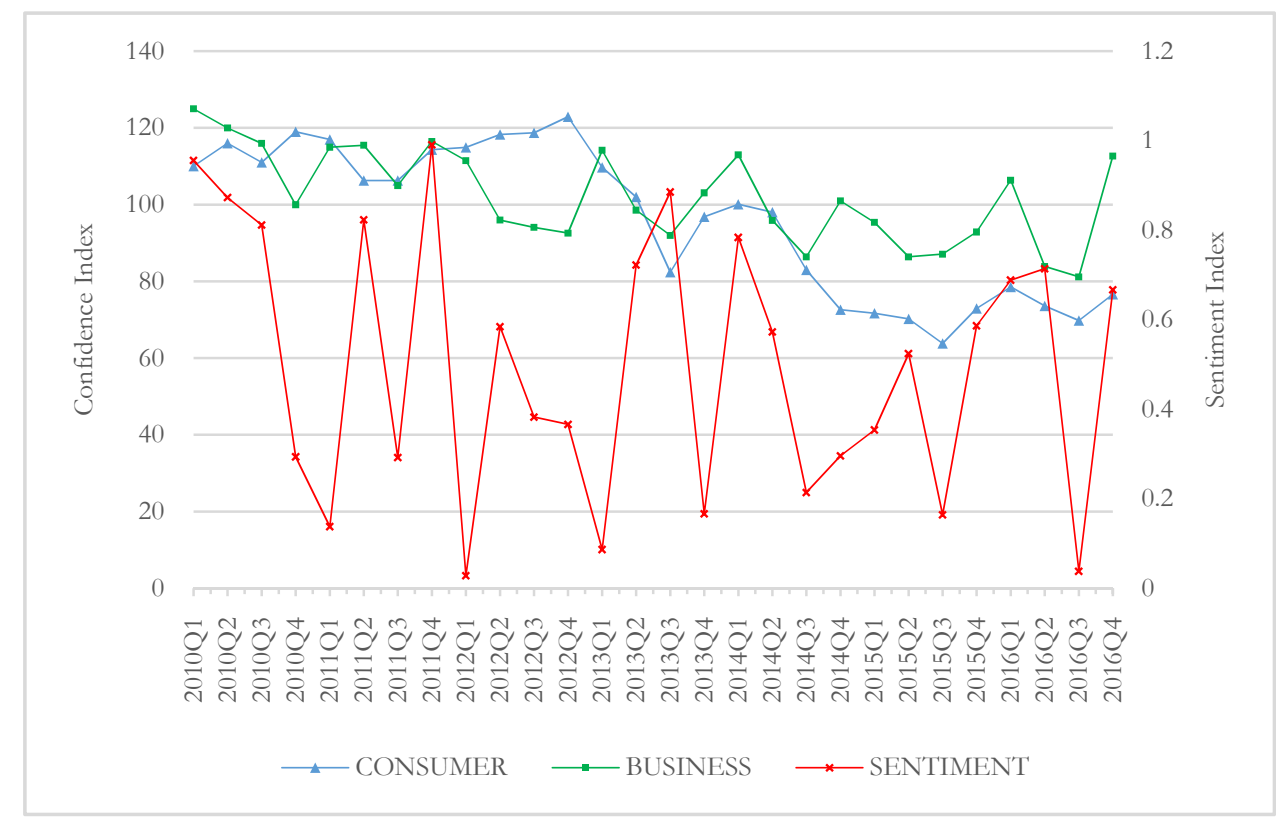

Figure 4. Consumer and business confidence index and the sentiment index, January $2010-$ December 2016

\subsection{The Impact of sentiments on housing market returns}

We first establish our housing market sentiment index's ability to predict future housing market returns. To do so, we estimate the following regression:

$R_{[t+1, t+b]}=\alpha+\beta_{1} S_{t}+\beta_{2}$ Festival $_{t}+\beta_{3}$ Holiday $_{t}+\beta_{4} R_{t}+\beta_{5} M 2_{t}+\beta_{6} B L R_{t}+\varepsilon_{t}$

where $R_{[t+1, t+b]}$ is the cumulative housing market return from month $t+1$ to month $t+b$ where $b=1,3,6,9$, and 12; and $S$ is the value of our sentiment index at month $t$. We account for seasonal effects (Kaplanski \& Levy, 2012) in Malaysia's housing market by including the variables Festival $t$ which is a binary variable that is ' 1 ' if month $t$ or its immediate preceding month has a major festival (Note 6); and Holiday ${ }_{t}$ which is a binary variable that is ' 1 ' if month $t$ coincides with the school holidays (Note 7). The festival and holiday season in Malaysia typically witnesses a growth in home-related transactions including but not limited 
to house purchase, moving homes, renovations and modifications to the home. It is also during these periods where developers typically offer various promotions and discounts on their housing projects. We control for current month returns $\left(R_{t}\right)$ to account for current transacted price trends and short-term reversals. We include the growth of M2 $\left(M 2_{t}\right)$ to control for effects arising from changing monetary policies over time. We also control for the influence the base lending rate $\left(B L R_{t}\right)$ has on consumer and investor propensity to take up a mortgage. Regression (3) estimates are in Table 3 below.

Table 3. Predicting future housing market returns with current housing market sentiments

\begin{tabular}{llllllll}
\hline Model & \multicolumn{1}{c}{$(\mathbf{1})$} & \multicolumn{1}{c}{$(\mathbf{2})$} & \multicolumn{1}{c}{$\mathbf{( 3 )}$} & \multicolumn{1}{c}{$(\mathbf{4})$} & \multicolumn{1}{c}{$\mathbf{( 5 )}$} & \multicolumn{1}{c}{$(\mathbf{6})$} & \multicolumn{1}{c}{$(\mathbf{7})$} \\
\hline Intercept & $0.548^{* * *}$ & $0.421^{* *}$ & $0.345^{* * *}$ & $0.217^{* *}$ & $0.639^{* * *}$ & $0.254^{* * *}$ & $0.358^{* *}$ \\
& $(0.08)$ & $(0.11)$ & $(0.13)$ & $(0.14)$ & $(0.33)$ & $(0.21)$ & $(0.33)$ \\
$S$ & $0.235^{* * *}$ & $0.331^{* * *}$ & $0.414^{* * *}$ & $0.364^{* * *}$ & $0.570^{*}$ & $0.481^{*}$ & $0.366^{*}$ \\
& $(0.05)$ & $(0.06)$ & $(0.11)$ & $(0.22)$ & $(0.20)$ & $(0.19)$ & $(0.23)$ \\
Festival & & & 0.114 & 0.210 & 0.254 & 0.244 & 0.211 \\
& & & $(0.15)$ & $(0.16)$ & $(0.18)$ & $(0.20)$ & $(0.15)$ \\
Holiday & & & 0.187 & 0.231 & 0.279 & 0.144 & 0.116 \\
& & & $(0.12)$ & $(0.13)$ & $(0.18)$ & $(0.11)$ & $(0.07)$ \\
$R$ & $0.212^{* * *}$ & $0.164^{* * *}$ & $0.101^{* * *}$ & $0.148^{* *}$ & $0.128^{*}$ & $0.173^{*}$ & $0.159^{*}$ \\
& $(0.03)$ & $(0.18)$ & $(0.10)$ & $(0.25)$ & $(0.33)$ & $(0.31)$ & $(0.44)$ \\
M2 & & 0.111 & 0.154 & 0.164 & 0.191 & 0.187 & 0.223 \\
& & $(0.14)$ & $(0.21)$ & $(0.26)$ & $(0.25)$ & $(0.22)$ & $(0.31)$ \\
BLR & & $-0.221^{* *}$ & $-0.219^{*}$ & $-0.197^{* *}$ & $-0.183^{* * *}$ & $-0.178^{* *}$ & $-0.187^{*}$ \\
& & $(0.12)$ & $(0.17)$ & $(0.15)$ & $(0.13)$ & $(0.18)$ & $(0.20)$ \\
$R^{2}$ & 0.2113 & 0.2203 & 0.2298 & 0.2315 & 0.2154 & 0.2332 & 0.2287 \\
\hline
\end{tabular}

Note: Model (1) is the basic model; Model (2) includes the control variables M2 and BLR; Model (3) includes all variables and controls for seasonal effects. The dependent variable for Models (1) - (3) is $R_{t+1}$. The dependent variable for Models (4) - (7) is $R_{t+1, t+3} ; R_{t+1, t+6} ; R_{t+1, t+9}$; and $R_{t+1, t+12}$ respectively. $* * * * *$, and $*$ denotes statistical significance at the $1 \%, 5 \%$, and $10 \%$ level respectively. Standard errors are in parentheses.

From Table 3 we can see that $S$ has a positive coefficient across all models. However, the statistical significance of the relationship weakens when we attempt to predict returns farther into the future (i.e. Models (5) - (7)). We can also see that the seasonal effects have no impact on housing market returns in Malaysia. Changes to monetary policy likewise, has no statistically significant effect on housing market returns. The base lending rate in contrast reduces housing market returns; an effect that is well within expectations since the interest expense on mortgage repayments lowers the returns sellers earn. In keeping with the literature on market sentiments, we re-estimate Models (3) - (7) in Table 3 but this time, instead of using a single measure of sentiment $\left(S_{t}\right)$, we consider the impact of optimistic and pessimistic sentiments on housing market returns. Here we dissect our sentiment index into two: $S+$ and $S-. S+$ equals $S$ when $S$ has a positive value while $S$ - equals $S$ when $S$ is negative. We denote both $S+$ and $S$ - as zero otherwise. The regression estimates are in Table 4 below. 
Table 4. The impact of optimistic and pessimistic sentiments on housing market returns

\begin{tabular}{llllll}
\hline Model & \multicolumn{1}{c}{$(\mathbf{1})$} & \multicolumn{1}{c}{$(\mathbf{2})$} & \multicolumn{1}{c}{$\mathbf{( 3 )}$} & \multicolumn{1}{c}{$(\mathbf{4})$} & \multicolumn{1}{c}{$\mathbf{( 5 )}$} \\
\hline Intercept & $0.145^{* * *}$ & $0.327^{* *}$ & $0.396^{* * *}$ & $0.413^{* * *}$ & $0.368^{* *}$ \\
& $(0.23)$ & $(0.25)$ & $(0.31)$ & $(0.22)$ & $(0.31)$ \\
$S+$ & $0.342^{* * *}$ & $0.358^{* *}$ & $0.367^{*}$ & $0.339^{*}$ & $0.351^{*}$ \\
& $(0.12)$ & $(0.24)$ & $(0.29)$ & $(0.21)$ & $(0.20)$ \\
$S-$ & -0.073 & -0.104 & -0.089 & -0.078 & -0.101 \\
& $(0.41)$ & $(0.34)$ & $(0.37)$ & $(0.31)$ & $(0.42)$ \\
Festival & 0.214 & 0.178 & 0.191 & 0.188 & 0.231 \\
& $(0.25)$ & $(0.21)$ & $(0.16)$ & $(0.28)$ & $(0.31)$ \\
Holiday & 0.237 & 0.222 & 0.238 & 0.256 & 0.161 \\
& $(0.16)$ & $(0.18)$ & $(0.11)$ & $(0.15)$ & $(0.19)$ \\
$R$ & $0.155^{* * *}$ & $0.160^{* *}$ & $0.165^{*}$ & $0.141^{*}$ & $0.167^{*}$ \\
& $(0.13)$ & $(0.19)$ & $(0.17)$ & $(0.12)$ & $(0.19)$ \\
M2 & 0.161 & 0.148 & 0.153 & 0.172 & 0.134 \\
& $(0.24)$ & $(0.21)$ & $(0.19)$ & $(0.14)$ & $(0.24)$ \\
BLR & $-0.221^{*}$ & $-0.217^{* *}$ & $-0.210^{* * *}$ & $-0.198^{* *}$ & $-0.207^{*}$ \\
& $(0.18)$ & $(0.14)$ & $(0.19)$ & $(0.23)$ & $(0.28)$ \\
$R^{2}$ & 0.2318 & 0.2327 & 0.2296 & 0.2112 & 0.2378 \\
\hline
\end{tabular}

The dependent variable for Models (1) - (5) is $R_{t+1, t+3} ; R_{t+1, t+6} ; R_{t+1, t+9}$; and $R_{t+1, t+12}$ respectively. ***, $* *$, and $*$ denotes statistical significance at the $1 \%, 5 \%$, and $10 \%$ level respectively. Standard errors are in parentheses.

The results in Table 4 are consistent with those in Table 3; that positive sentiments drive housing market returns. Although not statistically significant, we can also see that negative sentiments drive housing market returns down. The coefficient signs and statistical significance of all other variables are the same as those in Table 3.

However, we note that $R$ has the same coefficient sign as $S$ (Table 3 ) and $S+$ (Table 4 ). The statistical significance of $S / S+$ may be spurious if there is a positive correlation between $R$ and $S / S+$. To address this possibility, we re-estimate Equation 3 without $S$ before regressing the residuals on $S$, $S+$ and $S$-. The statistically significant positive relationship between $S$ and $S+$ on housing market returns persist as what we saw in Table 3 and 4 . Thus, it is safe to assume that the predictive power of $S / S+$ was not the result of its correlation with $R$.

\subsection{Individual Component Effects}

Indices offer a convenient manner of measuring and presenting data that can otherwise be difficult to visualize. However, aggregated data can sometimes lead to misleading interpretations and the development of ineffective policies. To ensure the validity of our interpretation, we disaggregate our sentiment index into its individual components i.e. the current values of NewStock, ResMort, HoldPer, SubSale, and the one-period lagged value of $P S Q M$ and regress these against $R_{[t+1, t+b]}$ as follows: 
$R_{[t+1, t+b]}=\alpha+\beta_{1}$ NewStock $_{t}+\beta_{2}$ ResMort $_{t}+\beta_{3}$ HoldPer $_{t}+\beta_{4}$ SubSale $_{t}+\beta_{5}$ PSQM $_{t-1}+$

$$
\beta_{6} \text { Festival }_{t}+\beta_{7} \text { Holiday }_{t}+\beta_{8} R_{t}+\beta_{9} M 2_{t}+\beta_{10} B L R_{t}+\varepsilon_{t}
$$

All variable definitions are as above. Equation 4 estimates are presented in Table 5.

Table 5. Sentiment component effects on housing market returns

\begin{tabular}{|c|c|c|c|c|c|}
\hline Model & (1) & (2) & (3) & (4) & (5) \\
\hline \multirow[t]{2}{*}{ Intercept } & $0.145^{* * *}$ & $0.327 * *$ & $0.396 * * *$ & $0.413 * * *$ & $0.368 * *$ \\
\hline & $(0.23)$ & $(0.25)$ & $(0.31)$ & $(0.22)$ & $(0.31)$ \\
\hline \multirow[t]{2}{*}{ NewStock } & $0.554 * * *$ & $0.513 * * *$ & $0.498^{* *}$ & $0.412^{* *}$ & $0.387 * *$ \\
\hline & $(0.14)$ & $(0.22)$ & $(0.34)$ & $(0.37)$ & $(0.41)$ \\
\hline \multirow[t]{2}{*}{ ResMort } & $0.331 * *$ & $0.304 * *$ & $0.277^{*}$ & $0.253^{*}$ & $0.224^{*}$ \\
\hline & $(0.23)$ & $(0.27)$ & $(0.35)$ & $(0.32)$ & $(0.44)$ \\
\hline \multirow[t]{2}{*}{ HoldPer } & $-0.224 *$ & $-0.244^{*}$ & -0.204 & -0.218 & -0.224 \\
\hline & $(0.36)$ & $(0.22)$ & $(0.31)$ & $(0.35)$ & $(0.44)$ \\
\hline \multirow[t]{2}{*}{ SubSale } & $0.301 * *$ & $0.299 *$ & 0.242 & 0.223 & 0.219 \\
\hline & $(0.28)$ & $(0.31)$ & $(0.44)$ & $(0.35)$ & $(0.33)$ \\
\hline \multirow[t]{2}{*}{$P S Q M_{t-1}$} & $0.386^{* * *}$ & $0.334 * * *$ & $0.317^{* *}$ & $0.300^{* *}$ & $0.285^{*}$ \\
\hline & $(0.24)$ & $(0.36)$ & $(0.22)$ & $(0.26)$ & $(0.33)$ \\
\hline \multirow[t]{2}{*}{ Festival } & 0.214 & 0.178 & 0.191 & 0.188 & 0.231 \\
\hline & $(0.25)$ & $(0.21)$ & $(0.16)$ & $(0.28)$ & $(0.31)$ \\
\hline \multirow[t]{2}{*}{ Holiday } & 0.237 & 0.222 & 0.238 & 0.256 & 0.161 \\
\hline & $(0.16)$ & $(0.18)$ & $(0.11)$ & $(0.15)$ & $(0.19)$ \\
\hline \multirow[t]{2}{*}{$R$} & $0.155^{* * *}$ & $0.160^{* *}$ & $0.165^{*}$ & $0.141^{*}$ & $0.167^{*}$ \\
\hline & $(0.13)$ & $(0.19)$ & $(0.17)$ & $(0.12)$ & $(0.19)$ \\
\hline \multirow[t]{2}{*}{$M 2$} & 0.161 & 0.148 & 0.153 & 0.172 & 0.134 \\
\hline & $(0.24)$ & $(0.21)$ & $(0.19)$ & $(0.14)$ & $(0.24)$ \\
\hline \multirow[t]{2}{*}{$B L R$} & $-0.221^{*}$ & $-0.217 * *$ & $-0.210 * * *$ & $-0.198 * *$ & $-0.207^{*}$ \\
\hline & $(0.18)$ & $(0.14)$ & $(0.19)$ & $(0.23)$ & $(0.28)$ \\
\hline$R^{2}$ & 0.2318 & 0.2327 & 0.2296 & 0.2112 & 0.2378 \\
\hline
\end{tabular}

The dependent variable for Models (1) - (5) is $R_{t+1} ; R_{t+1, t+3} ; R_{t+1, t+6} ; R_{t+1, t+9}$; and $R_{t+1, t+12}$ respectively. $*^{* *}, * *$, and $*$ denotes statistical significance at the $1 \%, 5 \%$, and $10 \%$ level respectively. Standard errors are in parentheses.

As we can see from Table 5, each of the five components of our housing market sentiment index display their predicted signs. The coefficient estimates are also consistent with those seen earlier in that the magnitude of effect remain relatively persistent and statistically significant for periods of up to 12 months except for HoldPer and SubSale. Most notably is that NewStock displays the greatest magnitude in absolute terms. Given that NewStock is a supply-side factor, its strong positive impact on house prices relative to other factors is rather surprising. This would seem to suggest that house prices in Malaysia are driven by property developer behaviour as opposed to house buyer or speculator behaviour. 


\subsection{Robustness Tests}

To ensure that our constructed sentiment index accurately reflects sentiments in the housing market of other states, we perform an out-of-sample test using data from the states not included in the earlier estimations (Note 8). We first calculate the monthly sentiment index for the out-of-sample states before estimating Equation 4 using data from the remaining states. As the earlier results show that the strongest statistical significance was at $b=1$, we only perform estimates using this parameter. Table 6 provides the regression estimates for every state in our dataset.

Table 6. Impact of sentiments (A) and sentiment components (B) on housing market returns, by state.

\begin{tabular}{|c|c|c|c|c|c|c|c|c|}
\hline & $\begin{array}{l}\text { Kuala } \\
\text { Lumpur }\end{array}$ & Selangor & Johor & Penang & Kedah & Perak & $\begin{array}{l}\text { Negeri } \\
\text { Sembilan }\end{array}$ & Malacca \\
\hline \multicolumn{9}{|c|}{ Panel A } \\
\hline Intercept & $\begin{array}{l}0.541 * * * \\
(0.28)\end{array}$ & $\begin{array}{l}0.551 * * \\
(0.21)\end{array}$ & $\begin{array}{l}0.415^{* * *} \\
(0.23)\end{array}$ & $\begin{array}{l}0.627 * * \\
(0.44)\end{array}$ & $\begin{array}{l}0.239 * * * \\
(0.38)\end{array}$ & $\begin{array}{l}0.254 * * * \\
(0.41)\end{array}$ & $\begin{array}{l}0.333 * * * \\
(0.22)\end{array}$ & $\begin{array}{l}0.311 * * * \\
(0.21)\end{array}$ \\
\hline$S$ & $\begin{array}{l}0.622 * * * \\
(0.24)\end{array}$ & $\begin{array}{l}0.628^{* * * *} \\
(0.31)\end{array}$ & $\begin{array}{l}0.437 * * * \\
(0.27)\end{array}$ & $\begin{array}{l}0.741^{* * *} \\
(0.38)\end{array}$ & $\begin{array}{l}0.247 * * * \\
(0.33)\end{array}$ & $\begin{array}{l}0.258^{* * *} \\
(0.25)\end{array}$ & $\begin{array}{l}0.329 * * * \\
(0.28)\end{array}$ & $\begin{array}{l}0.278^{* * *} \\
(0.31)\end{array}$ \\
\hline Festival & $\begin{array}{l}0.181 \\
(0.31)\end{array}$ & $\begin{array}{l}0.158 \\
(0.41)\end{array}$ & $\begin{array}{l}0.121 \\
(0.18)\end{array}$ & $\begin{array}{l}0.182 \\
(0.17)\end{array}$ & $\begin{array}{l}0.115 \\
(0.39)\end{array}$ & $\begin{array}{l}0.102 \\
(0.13)\end{array}$ & $\begin{array}{l}0.103 \\
(0.22)\end{array}$ & $\begin{array}{l}0.094 \\
(0.18)\end{array}$ \\
\hline Holiday & $\begin{array}{l}0.148 \\
(0.27)\end{array}$ & $\begin{array}{l}0.133 \\
(0.12)\end{array}$ & $\begin{array}{l}0.156 \\
(0.27)\end{array}$ & $\begin{array}{l}0.111 \\
(0.29)\end{array}$ & $\begin{array}{l}0.189 \\
(0.28)\end{array}$ & $\begin{array}{l}0.141 \\
(0.21)\end{array}$ & $\begin{array}{l}0.113 \\
(0.33)\end{array}$ & $\begin{array}{l}0.121 \\
(0.41)\end{array}$ \\
\hline$R$ & $\begin{array}{l}0.217 * * * \\
(0.81)\end{array}$ & $\begin{array}{l}0.269 * * * \\
(0.69)\end{array}$ & $\begin{array}{l}0.189 * * * \\
(0.58)\end{array}$ & $\begin{array}{l}0.273^{* * *} \\
(0.74)\end{array}$ & $\begin{array}{l}0.141^{* *} \\
(0.38)\end{array}$ & $\begin{array}{l}0.118 * * \\
(0.29)\end{array}$ & $\begin{array}{l}0.120 * * * \\
(0.33)\end{array}$ & $\begin{array}{l}0.143^{* *} \\
(0.45)\end{array}$ \\
\hline$M 2$ & $\begin{array}{l}0.111 \\
(0.55)\end{array}$ & $\begin{array}{l}0.141 \\
(0.41)\end{array}$ & $\begin{array}{l}0.150 \\
(0.39)\end{array}$ & $\begin{array}{l}0.132 \\
(0.46)\end{array}$ & $\begin{array}{l}0.114 \\
(0.31)\end{array}$ & $\begin{array}{l}0.139 \\
(0.29)\end{array}$ & $\begin{array}{l}0.118 \\
(0.11)\end{array}$ & $\begin{array}{l}0.108 \\
(0.14)\end{array}$ \\
\hline$B L R$ & $\begin{array}{l}-0.211 * * \\
(0.29)\end{array}$ & $\begin{array}{l}-0.237 * * \\
(0.24)\end{array}$ & $\begin{array}{l}-0.251^{* *} \\
(0.21)\end{array}$ & $\begin{array}{l}-0.231^{* *} \\
(0.28)\end{array}$ & $\begin{array}{l}-0.139 * * \\
(0.22)\end{array}$ & $\begin{array}{l}-0.175^{* *} \\
(0.25)\end{array}$ & $\begin{array}{l}-0.151 * * \\
(0.37)\end{array}$ & $\begin{array}{l}-0.138 * * \\
(0.41)\end{array}$ \\
\hline$R^{2}$ & 0.2415 & 0.2387 & 0.2341 & 0.2401 & 0.2043 & 0.2115 & 0.2124 & 0.2201 \\
\hline
\end{tabular}


Table 6 continued

\begin{tabular}{|c|c|c|c|c|c|c|c|c|}
\hline \multicolumn{9}{|c|}{ Panel B } \\
\hline Intercept & $\begin{array}{l}0.811 * * * \\
(0.41)\end{array}$ & $\begin{array}{l}0.745^{* * *} \\
(0.38)\end{array}$ & $\begin{array}{l}0.523 * * * \\
(0.43)\end{array}$ & $\begin{array}{l}0.779 * * \\
(0.34)\end{array}$ & $\begin{array}{l}0.245^{* *} \\
(0.39)\end{array}$ & $\begin{array}{l}0.251 * * * \\
(0.17)\end{array}$ & $\begin{array}{l}0.314 * * \\
(0.16)\end{array}$ & $\begin{array}{l}0.229 * * \\
(0.17)\end{array}$ \\
\hline NewStock & $\begin{array}{l}0.419 * * * \\
(0.22)\end{array}$ & $\begin{array}{l}0.522 * * * \\
(0.42)\end{array}$ & $\begin{array}{l}0.387 * * * \\
(0.39)\end{array}$ & $\begin{array}{l}0.448 * * * \\
(0.29)\end{array}$ & $\begin{array}{l}0.372 * * * \\
(0.21)\end{array}$ & $\begin{array}{l}0.323 * * * \\
(0.25)\end{array}$ & $\begin{array}{l}0.401 * * * \\
(0.18)\end{array}$ & $\begin{array}{l}0.433 * * * \\
(0.21)\end{array}$ \\
\hline ResMort & $\begin{array}{l}0.461 * * * \\
(0.33)\end{array}$ & $\begin{array}{l}0.489 * * * \\
(0.38)\end{array}$ & $\begin{array}{l}0.444 * * \\
(0.23)\end{array}$ & $\begin{array}{l}0.473 * * * \\
(0.43)\end{array}$ & $\begin{array}{l}0.212 * * \\
(0.24)\end{array}$ & $\begin{array}{l}0.263 * * \\
(0.33)\end{array}$ & $\begin{array}{l}0.233 * * \\
(0.33)\end{array}$ & $\begin{array}{l}0.212^{*} \\
(0.29)\end{array}$ \\
\hline HoldPer & $\begin{array}{l}-0.261 * * * \\
(0.31)\end{array}$ & $\begin{array}{l}-0.244 * * * \\
(0.41)\end{array}$ & $\begin{array}{l}-0.216^{* * *} \\
(0.48)\end{array}$ & $\begin{array}{l}-0.212^{* * *} \\
(0.26)\end{array}$ & $\begin{array}{l}-0.141^{* *} \\
(0.33)\end{array}$ & $\begin{array}{l}-0.132 * * \\
(0.55)\end{array}$ & $\begin{array}{l}-0.211^{* *} \\
(0.40)\end{array}$ & $\begin{array}{l}-0.177 * \\
(0.28)\end{array}$ \\
\hline SubSale & $\begin{array}{l}0.215^{* * *} \\
(0.38)\end{array}$ & $\begin{array}{l}0.374 * * * \\
(0.44)\end{array}$ & $\begin{array}{l}0.187 * * \\
(0.36)\end{array}$ & $\begin{array}{l}0.183 * * \\
(0.49)\end{array}$ & $\begin{array}{l}0.138 * \\
(0.38)\end{array}$ & $\begin{array}{l}0.164 * \\
(0.24)\end{array}$ & $\begin{array}{l}0.191 * * \\
(0.37)\end{array}$ & $\begin{array}{l}0.144 * * \\
(0.41)\end{array}$ \\
\hline$P S Q M_{t-1}$ & $\begin{array}{l}0.347^{* * *} \\
(0.89)\end{array}$ & $\begin{array}{l}0.499 * * * \\
(0.98)\end{array}$ & $\begin{array}{l}0.265^{* *} \\
(0.45)\end{array}$ & $\begin{array}{l}0.357 * * * \\
(0.30)\end{array}$ & $\begin{array}{l}0.184 * \\
(0.18)\end{array}$ & $\begin{array}{l}0.186^{* *} \\
(0.13)\end{array}$ & $\begin{array}{l}0.191 * * * \\
(0.68)\end{array}$ & $\begin{array}{l}0.148^{*} \\
(0.38)\end{array}$ \\
\hline Festival & $\begin{array}{l}0.431 \\
(0.31)\end{array}$ & $\begin{array}{l}0.338 \\
(0.14)\end{array}$ & $\begin{array}{l}0.139 \\
(0.14)\end{array}$ & $\begin{array}{l}0.318 \\
(0.43)\end{array}$ & $\begin{array}{l}0.055 \\
(0.34)\end{array}$ & $\begin{array}{l}0.032 \\
(0.27)\end{array}$ & $\begin{array}{l}0.101 \\
(0.21)\end{array}$ & $\begin{array}{l}0.084 \\
(0.18)\end{array}$ \\
\hline Holiday & $\begin{array}{l}0.267 \\
(0.68)\end{array}$ & $\begin{array}{l}0.246 \\
(0.79)\end{array}$ & $\begin{array}{l}0.148 \\
(0.73)\end{array}$ & $\begin{array}{l}0.243 \\
(0.83)\end{array}$ & $\begin{array}{l}0.051 \\
(0.39)\end{array}$ & $\begin{array}{l}0.036 \\
(0.21)\end{array}$ & $\begin{array}{l}0.114 \\
(0.48)\end{array}$ & $\begin{array}{l}0.087 \\
(0.33)\end{array}$ \\
\hline$R$ & $\begin{array}{l}0.113 * * * \\
(0.37)\end{array}$ & $\begin{array}{l}0.121 * * * \\
(0.45)\end{array}$ & $\begin{array}{l}0.135 * * * \\
(0.35)\end{array}$ & $\begin{array}{l}0.116 * * * \\
(0.40)\end{array}$ & $\begin{array}{l}0.122 * \\
(0.23)\end{array}$ & $\begin{array}{l}0.181 * * \\
(0.17)\end{array}$ & $\begin{array}{l}0.110 * * \\
(0.23)\end{array}$ & $\begin{array}{l}0.107 * * \\
(0.28)\end{array}$ \\
\hline$M 2$ & $\begin{array}{l}0.186 \\
(0.41)\end{array}$ & $\begin{array}{l}0.156 \\
(0.28)\end{array}$ & $\begin{array}{l}0.111 \\
(0.34)\end{array}$ & $\begin{array}{l}0.168 \\
(0.24) \\
\end{array}$ & $\begin{array}{l}0.110 \\
(0.43)\end{array}$ & $\begin{array}{l}0.067 \\
(0.42)\end{array}$ & $\begin{array}{l}0.103 \\
(0.33)\end{array}$ & $\begin{array}{l}0.098 \\
(0.41)\end{array}$ \\
\hline$B L R$ & $\begin{array}{l}-0.225^{* * *} \\
(0.38)\end{array}$ & $\begin{array}{l}-0.284 * * \\
(0.44)\end{array}$ & $\begin{array}{l}-0.237 * * * \\
(0.36)\end{array}$ & $\begin{array}{l}-0.313 * * * \\
(0.39)\end{array}$ & $\begin{array}{l}-0.178^{* *} \\
(0.23)\end{array}$ & $\begin{array}{l}-0.165^{* *} \\
(0.23)\end{array}$ & $\begin{array}{l}-0.195^{* *} \\
(0.34)\end{array}$ & $\begin{array}{l}-0.164 * \\
(0.31)\end{array}$ \\
\hline$R^{2}$ & 0.2227 & 0.2444 & 0.2879 & 0.2564 & 0.2794 & 0.2556 & 0.2348 & 0.2401 \\
\hline
\end{tabular}

$* * *, * *$, and $*$ denotes statistical significance at the $1 \%, 5 \%$, and $10 \%$ level respectively. Standard errors are in parentheses.

The results of our out-of-sample test in Panel A and B of Table 6 affirms the earlier findings that housing market sentiments drive Malaysian house prices. There also seems to be a clear difference in the magnitude of the relationship between the former (i.e. Kuala Lumpur, Selangor, Johor, and Penang) and latter (i.e. Kedah, Perak, Negeri Sembilan, and Malacca) states.

Finally, we address a possible concern of insufficient degrees of freedom arising from using monthly observations over a 7-year sample period. To do so, we re-estimate Equation 3 using daily observations. After excluding weekends, we have 1,827 observations, which should address this concern. The results are in Table 7 below. 
Table 7. Impact of sentiments (A) and sentiment components (B) on housing market returns, by state, daily frequency

\begin{tabular}{|c|c|c|c|c|c|c|c|c|}
\hline & $\begin{array}{l}\text { Kuala } \\
\text { Lumpur }\end{array}$ & Selangor & Johor & Penang & Kedah & Perak & $\begin{array}{l}\text { Negeri } \\
\text { Sembilan }\end{array}$ & Malacca \\
\hline \multicolumn{9}{|c|}{ Panel A } \\
\hline Intercept & $\begin{array}{l}0.443 * * * \\
(0.24)\end{array}$ & $\begin{array}{l}0.441 * * \\
(0.23)\end{array}$ & $\begin{array}{l}0.325^{* * *} \\
(0.21)\end{array}$ & $\begin{array}{l}0.522 * * \\
(0.41)\end{array}$ & $\begin{array}{l}0.222 * * * \\
(0.37)\end{array}$ & $\begin{array}{l}0.231 * * * \\
(0.33)\end{array}$ & $\begin{array}{l}0.311 * * * \\
(0.19)\end{array}$ & $\begin{array}{l}0.292 * * * \\
(0.25)\end{array}$ \\
\hline$S$ & $\begin{array}{l}0.521 * * * \\
(0.24)\end{array}$ & $\begin{array}{l}0.618 * * * \\
(0.31)\end{array}$ & $\begin{array}{l}0.417 * * * \\
(0.27)\end{array}$ & $\begin{array}{l}0.540 * * * \\
(0.38)\end{array}$ & $\begin{array}{l}0.235 * * * \\
(0.33)\end{array}$ & $\begin{array}{l}0.228 * * * \\
(0.25)\end{array}$ & $\begin{array}{l}0.333 * * * \\
(0.28)\end{array}$ & $\begin{array}{l}0.258 * * * \\
(0.31)\end{array}$ \\
\hline Festival & $\begin{array}{l}0.146 \\
(0.22)\end{array}$ & $\begin{array}{l}0.148 \\
(0.43)\end{array}$ & $\begin{array}{l}0.131 \\
(0.14)\end{array}$ & $\begin{array}{l}0.172 \\
(0.14)\end{array}$ & $\begin{array}{l}0.125 \\
(0.19)\end{array}$ & $\begin{array}{l}0.120 \\
(0.13)\end{array}$ & $\begin{array}{l}0.122 \\
(0.18)\end{array}$ & $\begin{array}{l}0.104 \\
(0.29)\end{array}$ \\
\hline Holiday & $\begin{array}{l}0.144 \\
(0.27)\end{array}$ & $\begin{array}{l}0.131 \\
(0.12)\end{array}$ & $\begin{array}{l}0.116 \\
(0.17)\end{array}$ & $\begin{array}{l}0.131 \\
(0.39)\end{array}$ & $\begin{array}{l}0.184 \\
(0.21)\end{array}$ & $\begin{array}{l}0.111 \\
(0.27)\end{array}$ & $\begin{array}{l}0.115 \\
(0.30)\end{array}$ & $\begin{array}{l}0.125 \\
(0.42)\end{array}$ \\
\hline$R$ & $\begin{array}{l}0.221 * * * \\
(0.56)\end{array}$ & $\begin{array}{l}0.231 * * * \\
(0.41)\end{array}$ & $\begin{array}{l}0.178^{* * *} \\
(0.51)\end{array}$ & $\begin{array}{l}0.213 * * * \\
(0.44)\end{array}$ & $\begin{array}{l}0.131 * * \\
(0.28)\end{array}$ & $\begin{array}{l}0.108 * * \\
(0.29)\end{array}$ & $\begin{array}{l}0.125^{* * *} \\
(0.31)\end{array}$ & $\begin{array}{l}0.151 * * \\
(0.46)\end{array}$ \\
\hline$M 2$ & $\begin{array}{l}0.100 \\
(0.51)\end{array}$ & $\begin{array}{l}0.118 \\
(0.37)\end{array}$ & $\begin{array}{l}0.149 \\
(0.32)\end{array}$ & $\begin{array}{l}0.123 \\
(0.44)\end{array}$ & $\begin{array}{l}0.141 \\
(0.25)\end{array}$ & $\begin{array}{l}0.137 \\
(0.22)\end{array}$ & $\begin{array}{l}0.121 \\
(0.16)\end{array}$ & $\begin{array}{l}0.118 \\
(0.24)\end{array}$ \\
\hline$B L R$ & $\begin{array}{l}-0.231 * * \\
(0.25)\end{array}$ & $\begin{array}{l}-0.234^{* *} \\
(0.22)\end{array}$ & $\begin{array}{l}-0.211^{* *} \\
(0.27)\end{array}$ & $\begin{array}{l}-0.244^{* *} \\
(0.29)\end{array}$ & $\begin{array}{l}-0.153 * * \\
(0.24)\end{array}$ & $\begin{array}{l}-0.178 * * \\
(0.29)\end{array}$ & $\begin{array}{l}-0.156^{* *} \\
(0.38)\end{array}$ & $\begin{array}{l}-0.139 * * \\
(0.23)\end{array}$ \\
\hline$R^{2}$ & 0.2325 & 0.2277 & 0.2222 & 0.2341 & 0.2133 & 0.2329 & 0.2301 & 0.2331 \\
\hline \multicolumn{9}{|c|}{ Panel B } \\
\hline Intercept & $\begin{array}{l}0.633 * * * \\
(0.43)\end{array}$ & $\begin{array}{l}0.645^{* *} \\
(0.34)\end{array}$ & $\begin{array}{l}0.532 * * * \\
(0.41)\end{array}$ & $\begin{array}{l}0.649 * * \\
(0.39)\end{array}$ & $\begin{array}{l}0.215 * * * \\
(0.35)\end{array}$ & $\begin{array}{l}0.253 * * \\
(0.13)\end{array}$ & $\begin{array}{l}0.324^{* * *} \\
(0.18)\end{array}$ & $\begin{array}{l}0.224 * * \\
(0.17)\end{array}$ \\
\hline NewStock & $\begin{array}{l}0.551 * * * \\
(0.21)\end{array}$ & $\begin{array}{l}0.512 * * \\
(0.41)\end{array}$ & $\begin{array}{l}0.477 * * * \\
(0.35)\end{array}$ & $\begin{array}{l}0.438 * * \\
(0.27)\end{array}$ & $\begin{array}{l}0.182^{* * *} \\
(0.21)\end{array}$ & $\begin{array}{l}0.133 * * * \\
(0.24)\end{array}$ & $\begin{array}{l}0.211^{* *} \\
(0.19)\end{array}$ & $\begin{array}{l}0.222 * * \\
(0.23)\end{array}$ \\
\hline ResMort & $\begin{array}{l}0.341 * * \\
(0.31)\end{array}$ & $\begin{array}{l}0.323 * * * \\
(0.34)\end{array}$ & $\begin{array}{l}0.298 * * * \\
(0.22)\end{array}$ & $\begin{array}{l}0.289 * * \\
(0.40)\end{array}$ & $\begin{array}{l}0.145 * * * \\
(0.23)\end{array}$ & $\begin{array}{l}0.153^{* *} \\
(0.23)\end{array}$ & $\begin{array}{l}0.222 * * * \\
(0.35)\end{array}$ & $\begin{array}{l}0.142 * \\
(0.27)\end{array}$ \\
\hline HoldPer & $\begin{array}{l}-0.259 * * * \\
(0.32)\end{array}$ & $\begin{array}{l}-0.234^{* * *} \\
(0.45)\end{array}$ & $\begin{array}{l}-0.266^{* * *} \\
(0.38)\end{array}$ & $\begin{array}{l}-0.242 * * \\
(0.20)\end{array}$ & $\begin{array}{l}-0.131 * * \\
(0.32)\end{array}$ & $\begin{array}{l}-0.133 * * \\
(0.51)\end{array}$ & $\begin{array}{l}-0.184 * * \\
(0.45)\end{array}$ & $\begin{array}{l}0.158 * * \\
(0.28)\end{array}$ \\
\hline SubSale & $\begin{array}{l}0.312^{* *} \\
(0.38)\end{array}$ & $\begin{array}{l}0.432 * * \\
(0.44)\end{array}$ & $\begin{array}{l}0.389 * \\
(0.36)\end{array}$ & $\begin{array}{l}0.411 * * * \\
(0.39)\end{array}$ & $\begin{array}{l}0.178^{* *} \\
(0.23)\end{array}$ & $\begin{array}{l}0.135^{* *} \\
(0.23)\end{array}$ & $\begin{array}{l}0.190 * * * \\
(0.34)\end{array}$ & $\begin{array}{l}0.164 * \\
(0.31)\end{array}$ \\
\hline$P S Q M_{t-1}$ & $\begin{array}{l}0.507 * * * \\
(0.66)\end{array}$ & $\begin{array}{l}0.489 * * * \\
(0.67)\end{array}$ & $\begin{array}{l}0.345 * * * \\
(0.35)\end{array}$ & $\begin{array}{l}0.398 * * \\
(0.28)\end{array}$ & $\begin{array}{l}0.167 * * \\
(0.18)\end{array}$ & $\begin{array}{l}0.155^{*} \\
(0.13) \\
\end{array}$ & $\begin{array}{l}0.179 * * \\
(0.55)\end{array}$ & $\begin{array}{l}0.138 * * * \\
(0.34)\end{array}$ \\
\hline Festival & $\begin{array}{l}0.231 \\
(0.31) \\
\end{array}$ & $\begin{array}{l}0.248 \\
(0.17)\end{array}$ & $\begin{array}{l}0.149 \\
(0.15) \\
\end{array}$ & $\begin{array}{l}0.338 \\
(0.42) \\
\end{array}$ & $\begin{array}{l}0.075 \\
(0.31) \\
\end{array}$ & $\begin{array}{l}0.042 \\
(0.21)\end{array}$ & $\begin{array}{l}0.111 \\
(0.25)\end{array}$ & $\begin{array}{l}0.044 \\
(0.19) \\
\end{array}$ \\
\hline Holiday & $\begin{array}{l}0.166 \\
(0.64)\end{array}$ & $\begin{array}{l}0.156 \\
(0.49) \\
\end{array}$ & $\begin{array}{l}0.137 \\
(0.53) \\
\end{array}$ & $\begin{array}{l}0.213 \\
(0.43)\end{array}$ & $\begin{array}{l}0.081 \\
(0.49)\end{array}$ & $\begin{array}{l}0.076 \\
(0.31) \\
\end{array}$ & $\begin{array}{l}0.104 \\
(0.38)\end{array}$ & $\begin{array}{l}0.077 \\
(0.34)\end{array}$ \\
\hline$R$ & $\begin{array}{l}0.103^{* *} \\
(0.31)\end{array}$ & $\begin{array}{l}0.111 * * * \\
(0.42)\end{array}$ & $\begin{array}{l}0.145^{* *} \\
(0.39)\end{array}$ & $\begin{array}{l}0.126^{* *} \\
(0.44)\end{array}$ & $\begin{array}{l}0.123^{*} \\
(0.21) \\
\end{array}$ & $\begin{array}{l}0.155^{* *} \\
(0.11)\end{array}$ & $\begin{array}{l}0.116^{* *} \\
(0.21)\end{array}$ & $\begin{array}{l}0.117^{* *} \\
(0.27)\end{array}$ \\
\hline$M 2$ & $\begin{array}{l}0.156 \\
(0.33) \\
\end{array}$ & $\begin{array}{l}0.126 \\
(0.27) \\
\end{array}$ & $\begin{array}{l}0.104 \\
(0.22)\end{array}$ & $\begin{array}{l}0.158 \\
(0.29) \\
\end{array}$ & $\begin{array}{l}0.114 \\
(0.42)\end{array}$ & $\begin{array}{l}0.077 \\
(0.32)\end{array}$ & $\begin{array}{l}0.113 \\
(0.23) \\
\end{array}$ & $\begin{array}{l}0.058 \\
(0.31) \\
\end{array}$ \\
\hline$B L R$ & $\begin{array}{l}-0.256^{*} \\
(0.28)\end{array}$ & $\begin{array}{l}-0.267 * \\
(0.23)\end{array}$ & $\begin{array}{l}-0.271 * \\
(0.29)\end{array}$ & $\begin{array}{l}-0.263 * * \\
(0.24)\end{array}$ & $\begin{array}{l}-0.212^{*} \\
(0.33)\end{array}$ & $\begin{array}{l}-0.269 * * \\
(0.21)\end{array}$ & $\begin{array}{l}-0.275^{* *} \\
(0.23)\end{array}$ & $\begin{array}{l}-0.228^{* *} \\
(0.30)\end{array}$ \\
\hline$R^{2}$ & 0.2631 & 0.2224 & 0.2824 & 0.2813 & 0.2034 & 0.2124 & 0.2318 & 0.2415 \\
\hline
\end{tabular}

The dependent variable is $R_{[t+1, t+b]}$, where $b=30 . * * * * *$, and $*$ denotes statistical significance at the $1 \%, 5 \%$, and $10 \%$ level respectively. Standard errors are in parentheses. 
On the whole, the results in Table 7 are qualitatively similar with the earlier findings that housing market sentiment is a strong driver of housing market returns, and that the cooling measures introduced by the government and central bank have so far been ineffective in dampening sentiment.

\section{Discussion \& Conclusion}

The results above lead us to a few key observations. First, housing market optimism drives house prices in Malaysia. Pessimism meanwhile does not bring prices down. However, as opposed to the literature (Zhou, 2017; Berger \& Turtle, 2015; Stambaugh et al., 2012), periods of market optimism are followed by higher rather than lower housing market returns. We believe that this could be the result of substantial growth in a recent trend to hit the Malaysian housing market - rental returns. A casual observation of the classifieds shows that instead of earning returns through capital gains, the housing market is flooded with listings citing substantial rental opportunities, largely driven by the advent of crowd-sourced accommodation platforms such as Airbnb. Our personal correspondence with ten real estate negotiators (all of whom wished to remain anonymous) indicate that a substantial number of deals closed were the result of optimism in the potential rental returns, rather than capital gains. The greater the potential rental return, the higher the price buyers were willing to pay for the house.

Second, disaggregating our housing market sentiment measure into its individual components, we find property developer behaviour to have the greatest influence on housing market returns as compared to other factors such as mortgage terms and previously transacted prices. This observation is rather interesting especially since our proxy for developer behaviour is a supply-side variable that is normally negatively related to prices. What we can infer is instead of lowering prices, increments in the supply of new residential units by developers is a signal of further optimism in the market. Because pricing mechanisms in property markets are often opaque, developers are deemed to be more informed of future prospects in the market as compared to house buyers. As a result, new project launches send strong signals to other players that the market remains robust, hence the continued growth in prices.

Our results also show a disparity in the effects of market optimism in different states. The effects of optimism are much stronger in the states of Kuala Lumpur, Selangor, Johor, and Penang, as compared to Kedah, Perak, Negeri Sembilan, and Malacca. Understandably, house prices in the former four states are more strongly driven by housing market sentiments as compared to the latter four owing to the substantial amounts of development taking place in the former. The latter in contrast, are geographically larger with a much wider dispersion of population and development. Second, throughout history agriculture has been the main economic activity in the latter states. Infrastructural development progressed at a much slower pace. It is only in recent years that buyers consider Seremban, the capital of Negeri Sembilan, a satellite city to Kuala Lumpur, hence the stronger impact of sentiments in the state.

The findings of this study have a number of policy implications. First, we provide evidence that out of all the proxies, NewStock had the strongest influence on housing market 
sentiments and returns. This suggests that contrary to popular opinion, developers instead of individual sellers drive housing market sentiments in Malaysia. In fact, homeowners looking to sell have an incentive to set asking prices that match the prices of new developments in the area. When new projects are sold at high prices, there is an incentive for real estate negotiators to keep the seller's asking price high. Driven by the optimism in the initial few transactions, more sellers will follow suit driving sentiments and subsequently prices higher. Second, the populace of an emerging market like Malaysia remains unsophisticated in their investment choices. Many investors still prefer real estate as the 'safer' choice compared to financial securities. A lack of attractive investment alternatives in the financial markets also contribute to the demand for real estate investment. To address the first issue, local governments can begin by reducing the number of new projects approved. As of Q3 2017, there is approximately 5.4 million residential units in stock with a further 480,000 units of incoming supply, and another 427,692 units planned across the country. With an estimated population of 32 million (as of 2017), the number of persons per residential unit will be about 5 when all current projects are completed. In comparison, the average household size in Malaysia is 4.31 persons. These simple calculations suggest that the current stock of residential units are sufficient to house the country's population. Measures should be taken to ensure that the growth of new housing projects approved should be in tandem with population requirements. Addressing the second issue is a matter of financial education, provision of investment incentives such as tax exemptions, and a reduction in the barriers to entry for new investors. While prudence is always advised, liberalization of the financial markets to allow a wider range of investment alternatives is also required.

We conclude by providing a few suggestions for future research. First, we recommend further investigation of housing market sentiments with respect to rental returns. The costs and restrictions in property transactions can be substantial. As a result, many young adults are looking to renting as opposed to owning as a means to independent living. How then does the prospect of future rental receipts factor into housing market sentiments, especially since there is no guarantee of occupancy given the growing supply of residential units? Second, although Bank Negara's lending policies are considered one of the most prudent, it does not stop the non-performance of housing loans. To develop more holistic measures in addressing housing market sentiments, one can study the bank-specific factors that dampen or drive sentiments. Finally, one may also choose to study the influence of micro-factors (e.g. house characteristics, address, neighbourhood demographics) on housing market sentiments to assist in the development of policies that are more targeted.

Notes

Note 1. In Malaysia, a sub-sale is when a buyer buys a house from the developer (under a new project) only to sell it off in the secondary market.

Note 2. Housing developers in Malaysia are legally allowed to extend the completion date of a housing project up to 48 months. The real property gains tax rate after the 48th month of ownership is $15 \%$. This provides a significant incentive for sellers to hold-off a sub-sale until after that period. 
Note 3. A transacted price of RM1 million in our dataset lies in the 90th percentile. In comparison, the average transacted price across all four states is approximately RM600,000. A premium of RM400,000 above the average price would suggest some degree of confidence in the housing market.

Note 4. We assume that the sentiment proxies are related to the expected housing market returns and uncorrelated with unpredictable return shocks.

Note 5. Both correlation coefficients are statistically significant at the $1 \%$ level.

The major festivals in Malaysia are Chinese New Year (January - February); Eid al-Fitr; Diwali (typically October - November); and Christmas.

Note 6. School holidays in Malaysia are typically in the months of March, May, September, and November to December.

Note 7. The remaining states in our dataset are Kedah, Perak, Negeri Sembilan, and Melaka.

\section{References}

Agarwal, S., Hu, L., \& Huang, X. (2015). Rushing into the American dream? House prices growth and the timing of homeownership. Review of Finance, 20(6), 2183-2218. https://doi.org/10.1093/rof/rfv063

Augustin, R. (2017, November 15). No, property market won't crash in 2018, say other experts. Free Malaysia Today. Retrieved from http://www.freemalaysiatoday.com/category/nation/2017/11/15/no-property-market-wont-cra sh-in-2018-say-other-experts/ (accessed 4 February 2018)

Baker, M., \& Stein, J. C. (2004). Market liquidity as a sentiment indicator. Journal of Financial Markets, 7(3), 271-299. https://doi.org/10.1016/j.finmar.2003.11.005

Baker, M. \& Wurgler, J. (2006). Investor sentiment and the cross-section of stock returns. The Journal of Finance, 61(4), 1645-1680. https://doi.org/10.1111/j.1540-6261.2006.00885.x

Baker, M. \& Wurgler, J. (2007). Investor Sentiment in the Stock Market. The Journal of Economic Perspectives, 21(2), 129-152. https://doi.org/10.1257/jep.21.2.129

Bank Negara Malaysia. (2011, November 18). Measures to Promote Responsible Financing Practices. Bank Negara Malaysia Press Statements. Retrieved from http://www.bnm.gov.my/index.php?ch=en_press\&pg=en_press_all\&ac=2350\&lang=en (accessed 12 January 2018).

Bank Negara Malaysia. (2010, November 3). Immediate implementation of a maximum loan-to-value (LTV) ratio of 70\%, Bank Negara Malaysia Press Statements. Retrieved from http://www.bnm.gov.my/index.php?ch=8\&pg=14\&ac=2159 (accessed 22 December 2017).

Bank Negara Malaysia. (2013, July 5). Measures to Further Promote a Sound and Sustainable Household Sector. Bank Negara Malaysia Press Statements. Retrieved from http://www.bnm.gov.my/index.php?ch=en_press\&pg=en_press_all\&ac=2841 (accessed 22 
December 2017).

Berger, D., Turtle, H. (2015). Sentiment bubbles. Journal of Financial Markets, 23, 59-74. https://doi.org/10.1016/j.finmar.2015.01.002

Berry, J., McGreal, S., Stevenson, S. \& Young, J. (2001). Government intervention and impact on the housing market in Greater Dublin. Housing Studies, 2001, 16(6), 755-769. https://doi.org/10.1080/02673030120090520

Burnside, C., Eichenbaum, M., \& Rebelo, S. (2016). Understanding booms and busts in housing markets. Journal of Political Economy, 124(4), 1088-1147. https://doi.org/10.1086/686732

Chambers, M., Garriga, C., \& Schlagenhauf, D. E. (2009). Housing policy and the progressivity of income taxation. Journal of Monetary Economics, 56(8), 1116-1134. https://doi.org/10.1016/j.jmoneco.2009.10.007

Chang, K. L. (2014, September 20). Why developer interest-bearing schemes should be banned. The Star Online. Retrieved from http://www.thestar.com.my/Business/Business-News/2014/09/20/Saying-no-to-DIBS-It-shoul d-continue-to-be-prohibited-in-the-interest-of-first-time-house-buyers/?style=biz (accessed 22 December 2017)

Cho, S. W. S., \& Francis, J. L. (2011). Tax treatment of owner occupied housing and wealth inequality. Journal of Macroeconomics, 33(1), https://doi.org/10.1016/j.jmacro.2010.09.002

Clayton, J. (1997). Are housing price cycles driven by irrational expectations? The Journal of Real Estate Finance and Economics, 14(3), 341-363. https://doi.org/10.1023/A:1007766714810

Clayton, J., Ling, D. C., \& Naranjo, A. (2009). Commercial real estate valuation: fundamentals versus investor sentiment. The Journal of Real Estate Finance and Economics, 38(1), 5-37. https://doi.org/10.1007/s11146-008-9130-6

Clayton, J., MacKinnon, G., \& Peng, L. (2008). Time variation of liquidity in the private real estate market: An empirical investigation. Journal of Real Estate Research, 30(2), 125-160.

Daily Express. (2015, April 13). Property market in a wait and see mode, Daily Express. Retrieved from http://www.dailyexpress.com.my/news.cfm?NewsID=98912 (accessed 2 May 2015)

Floetotto, M., Kirker, M., \& Stroebel, J. (2016). Government intervention in the housing market: Who wins, who loses? Journal of Monetary Economics, 80, 106-123. https://doi.org/10.1016/j.jmoneco.2016.04.005

Gallimore, P., \& Gray, A. (2002). The role of investor sentiment in property investment decisions. Journal of Property Research, 19(2), 111-120. https://doi.org/10.1080/09599910110110671 
Genesove, D., \& Mayer, C. (2001). Loss aversion and seller behavior: Evidence from the housing market. The Quarterly Journal of Economics, 116(4), 1233-1260. https://doi.org/10.1162/003355301753265561

Han, L. (2013). Understanding the puzzling risk-return relationship for housing. Review of Financial Studies, 26(4), 877-928. https://doi.org/10.1093/rfs/hhs181

Herrera, S. \& Perry, G.E. (2003), Tropical Bubbles: Asset Prices in Latin America, 1980-2001. In Hunter, W.C., Kaufman, G.G. \& Pomerleano, M. (Eds.), Asset price bubbles: implications for monetary, regulatory, and international policies. MIT Press, Cambridge, Mass.

Hisyam, K. (2013, July 22). Are we heading towards a property bubble?. KiniBiz. Retrieved from

http://www.kinibiz.com/story/issues/38574/are-we-heading-towards-a-property-bubble.html (accessed 25 May 2014).

Huang, D., Jiang, F., Tu, J., \& Zhou, G. (2014). Investor sentiment aligned: a powerful predictor of stock returns. Review of Financial Studies, 28(3), 791-837. https://doi.org/10.1093/rfs/hhu080

Hui, E. C. \& Wang, Z. (2014). Market sentiment in private housing market. Habitat International, 44, 375-385. https://doi.org/10.1016/j.habitatint.2014.08.001

Hui, E. C., Zheng, X., and Wang, H. (2013). Investor sentiment and risk appetite of real estate $\begin{array}{llll}\text { security market. } & \text { Applied } & \text { Economics, } & \text { 45(19), }\end{array}$ https://doi.org/10.1080/00036846.2012.681028

IMF. (2015). 2014 ARTICLE IV CONSULTATION_STAFF REPORT; PRESS RELEASE; AND STATEMENT BY THE EXECUTIVE DIRECTOR FOR MALAYSIA (Country Report No. 15/58), IMF Country Report. Available from http://www.imf.org/external/pubs/ft/scr/2015/cr1558.pdf (accessed 14 December 2017).

Jin, C., Soydemir, G., \& Tidwell, A. (2014). The US housing market and the pricing of risk: Fundamental analysis and market sentiment. Journal of Real Estate Research, 36(2), 187-219. https://www.jstor.org/stable/24888727

Kamalavacini, R. (2014, September 12). Property players hit by cooling measures. The Malaysian Reserve. Retrieved from http://themalaysianreserve.com/main/news/corporate-malaysia/6455-property-players-hit-bycooling-measures (accessed 25 December 2017).

Kaplanski, G, \& Levy, H. (2012). Real estate prices: An international study of seasonality's sentiment effect. Journal of Empirical Finance, 19(1), 123-146. https://doi.org/10.1016/j.jempfin.2011.11.004

Kaur, M. (2017, November 14). Property market will be badly hit in 2018, says expert. Free Malaysia Today. Retrieved from http://www.freemalaysiatoday.com/category/nation/2017/11/14/property-market-will-be-badl y-hit-in-2018-says-expert/ (accessed 4 February 2018) 
Lee, A. K. L., Sinnakkannu, J., \& Ramasamy, S. R. (2015, October 3). Housing Affordability: A Malaysian Perspective. Paper presented at: The $11^{\text {th }}$ Asian Academy of Management International Conference, Penang Island, Malaysia.

Ling, D. C., Naranjo, A., \& Scheick, B. (2014). Investor sentiment, limits to arbitrage and private market returns. Real Estate Economics, 42(3), 531-577. https://doi.org/10.1111/1540-6229.12037

Ling, D. C., Ooi, J. T. L., \& Le T, T, T. (2015). Explaining house price dynamics: Isolating the role of nonfundamentals. Journal of Money, Credit and Banking, 47(S1), 87-125, https://doi.org/10.1111/jmcb.12194

Malmendier, U., \& Tate, G. (2005). CEO overconfidence and corporate investment. The Journal of Finance, 60(6), 2661-2700. https://doi.org/10.1111/j.1540-6261.2005.00813.x

Malmendier, U, \& Tate, G. (2008). Who makes acquisitions? CEO overconfidence and the market's reaction. Journal of Financial Economics, 89(1), 20-43. https://doi.org/10.1016/j.jfineco.2007.07.002

Miller, N., \& Pandher, G. (2008). Idiosyncratic volatility and the housing market. Journal of Housing Research, 17(1), 13-32, https://www.jstor.org/stable/24861451

Mok, O. (2015, January 2), "With promise of real estate boon, property investor clubs boom", The Malaysian Insider, available at: http://www.themalaysianinsider.com/malaysia/article/with-promise-of-real-estate-boon-prope rty-investor-clubs-boom (accessed 25 December 2017).

Piazessi, M., and Schneider, M. (2009). Momentum traders in the housing market: Survey evidence and a search model. The American Economic Review, 99(2), 406-411. https://doi.org/10.1257/aer.99.2.406

Pomerleano, M. (2003), The Morning After: Restructuring in the Aftermath of an Asset Bubble. In Pomerleano, M., Hunter, W.C., Kaufman, G.G. \& Pomerleano, M. (Eds.), Asset price bubbles: implications for monetary, regulatory, and international policies. MIT Press, Cambridge, Mass.

Soo, C. K. (2013). Quantifying animal spirits: news media and sentiment in the housing market. The Stephen M. Ross School of Business at the University of Michigan Research Paper Series.

Stambaugh, R. F., Yu, J., \& Yuan, Y. (2012). The short of it: Investor sentiment and anomalies. Journal of Financial Economics, 288-302. https://doi.org/10.1016/j.jfineco.2011.12.001

The Star Online. (2013, June 27). What is DIBS, plus the pros and cons of this controversial scheme. The Star Online. Retrieved from http://www.starproperty.my/index.php/articles/investment/what-is-dibs-plus-the-pros-and-con s-of-dibs/ (accessed 26 December 2017). 
Tse, R. Y. C., Ho, C. W., \& Ganesan, S. (1999). Matching housing supply and demand: an empirical study of Hong Kong's market. Construction Management \& Economics, 17(5), 625-633. https://doi.org/10.1080/014461999371231

Yeong, E. (2013, October 30). Higher property gains tax, DIBS ban are 'good'. The Sun Daily. Retrieved from http://www.thesundaily.my/news/868889 (accessed 18 December 2017).

Yeong, E. (2014, October 9). Housing affordability not addressed in Budget 2014. The Sun Daily. Retrieved from http://www.thesundaily.my/news/1193131 (accessed 18 December 2017).

Zhou, Z. (2017). Housing market sentiment and intervention effectiveness: Evidence from China, Emerging Market Review, (in press).

\section{Copyright Disclaimer}

Copyright for this article is retained by the author(s), with first publication rights granted to the journal.

This is an open-access article distributed under the terms and conditions of the Creative Commons Attribution license (http://creativecommons.org/licenses/by/3.0/). 